\title{
POTENSI TEGAKAN TINGKAT TIANG DAN POHON DI AREAL KHDTK HUTAN DIKLAT LOA HAUR KECAMATAN LOA JANAN KABUPATEN KUTAI KARTANEGARA PROVINSI KALIMANTAN TIMUR
}

\author{
Sukirno $^{1}$, M. Taufan Tirkaamiana ${ }^{2}$, Jumani $^{2}$, dan Heni Emawati ${ }^{2}$ \\ ${ }^{1}$ Kehutanan, Fakultas Pertanian, Universitas 17 Agustus 1945 Samarinda, Indonesia. \\ ${ }^{2}$ Fakultas Pertanian, Universitas 17 Agustus 1945 Samarinda 75124, Indonesia. \\ E-Mail: sukirno@untag-smd.ac.id; jumani@untag-smd.ac.id
}

\begin{abstract}
ABSTRAK
Potensi Tegakan Tingkat Tiang dan Pohon di Areal KHDTK Hutan Diklat Loa Haur Kecamatan Loa Janan Kabupaten Kutai Kartanegara Provinsi Kalimantan Timur. Kegiatan Penataan Hutan Diklat diperlukan untuk memberikan gambaran yang jelas mengenai potensi hutan diklat yang akan dikelola. Dari Hasil kegiatan penataan tersebut akan diperoleh potensi mengenai keadaan hutan, topografi, iklim serta keadaan masyarakat yang ada di dalam dan sekitar hutan, yang mana data tersebut nantinya akan dipergunakan sebagai dasar dalam menyusun pengelolaan hutan lebih lanjut sesuai dengan kondisi lapangan dan program diklat yang akan dilaksanakan.

Tujuan dari Penelitian ini adalah untuk mengetahui potensi tegakan tingkat Tiang di areal KHDTK Hutan Diklat Loa Haur Balai Diklat LHK Samarinda, Mengetahui potensi tegakan tingkat Pohon di areal KHDTK Hutan Diklat Loa Haur Balai Diklat LHK Samarinda dan Mengetahui keanekaragaman jenis tegakan yang mendominasi areal KHDTK Hutan Diklat Loa Haur Balai Diklat LHK Samarinda. Metode yang digunakan dalam Penelitian dan pengambilan data di lapangan adalah dengan menggunakan teknik purposive sampling. Adapun metode pengujian Potensi Tegakan dengan menggunakan Rumus Total Volume dalam satuan Kubikasi dimana parameter yang diukur meliputi Diameter tegakan, Tinggi tegakan dan jumlah Populasi keseluruhan Plot penelitian.

Sedangkan untuk nilai keanekaragaman jenis dihitung dengan menggunakan rumus Nilai Indeks Keragaman Shannon-Wiener 1992.

Hasil yang didapatkan berdasarkan rekapitulasi dari 5 plot sampel penelitian seluas $26 \mathrm{Ha}$ dengan Intensitas Sampling sebesar 5\% pada Areal KHDTK Hutan Diklat Loa Haur diperoleh hasil bahwa Potensi tegakan tingkat Tiang sebesar $111 \mathrm{~m}^{3}$ dengan jumlah populasi sebanyak 1.159 tegakan atau sama dengan $4,269 \mathrm{~m}^{3} / \mathrm{ha}$ dengan populasi 45 tegakan/ha. Sedangkan pada tingkat Pohon diperoleh potensi sebesar $189,7 \mathrm{~m}^{3}$ dengan jumlah populasi sebanyak 497 tegakan atau sama dengan 7,30 $\mathrm{m}^{3} /$ ha dengan populasi 19 tegakan/ha.

Nilai indeks keanekaragaman H' pada kelompok jenis Meranti tingkat Tiang sebesar 2,14 dan tingkat pohon sebesar 1,72. pada kelompok jenis Rimba Campuran Nilai indeks Keanekaragaman tingkat Tiang sebesar 1,98 dan tingkat Pohon sebesar 2,31. Baik untuk Kelompok Meranti dan Kelompok Rimba Campuran Nilai Indeks Keanekaragaman H' masih termasuk dalam kategori Sedang. Pada kelompok Kayu Indah nilai indeks Keanekaragaman tingkat Tiang sebesar 1,20 dan tingkat Pohon 0,94 nilai H' pada kelompok jenis ini nilai indeks keanekaragamannya masih tergolong dalam kategori.

Dan berdasarkan hasil penelitian terhadap 5 plot sampel seluas 26 Ha dengan intensitas sampling 5\% diketahui bahwa tegakan yang memiliki nilai indeks keanekaragaman tertinggi baik untuk tingkat Tiang dan Pohon adalah jenis Mahang (Macaranga sp), dimana untuk tegakan tingkat Tiang diperoleh jumlah tegakan sebanyak 312 tegakan dengan nilai indeks keanekaragaman 0,153, sedangkan tegakan tingkat Pohon dengan jumlah tegakan sebanyak 94 pohon nilai indeks keanekaragamannya sebesar 0,137 , dan nilai indeks keanekaragaman ini masih termasuk dalam kategori.
\end{abstract}

Kata kunci : Potensi tegakan, tingkat tiang, pohon, keanekaragaman jenis.

\begin{abstract}
Potency of Pole and Tree Level Stand in Education and Training KHDTK forest areal Loa Haur Kecamatan Loa Janan Kabupaten Kutai Kartanegara East Kalimantan Province. The activity of
\end{abstract}


education and training forest management is needed to give a clear description regarding education and training forest potency which will be managed. From that management activity result then will be obtained the potency of forest condition, topography, climate and the condition of community inside and the vicinity, in which, those datas, in turn, will be used as a base for arranging further forest management as per field condition and the scheduled training.

The aim of this research is to understand potency of pole level stand in Education and Training KHDTK forest areal Loa Haur Environment and Forestry Center Samarinda, understand potency of tree level stand in Education and Training KHDTK forest areal Loa Haur Environment and Forestry Center Samarinda and understand the diversity of stands type that dominate Education and Training KHDTK forest areal Loa Haur Environment and Forestry Center Samarinda. Used method in the research and data sampling in the field is using purposive sampling technic

While diversity value is counted by using Diversity Index Value Shannon-Wiener 1992.

The result obtained base on recapitulation of 5 plots from 26 ha research sample with $5 \%$ sampling intensity in Education and Training KHDTK forest areal Loa Haur generate result that pole level stand is $111 \mathrm{~m}^{3}$ with total population 1.159 stand or equal with $4,269 \mathrm{~m}^{3} /$ ha and population 45 stands $/$ ha. While in tree level stand resulted potency $189,7 \mathrm{~m}^{3}$ with total population 497 stand or equal to $7,30 \mathrm{~m}^{3} / \mathrm{ha}$ and population 19 stands /ha.

Diversity index value H' for Meranti pole level type group is 2,14 and tree level is 1,72. Diversity index value for Mixed Rimba pole level is 1,98 and tree level is 2,31. Both Meranti group and Mixed Rimba group have medium category of diversity index value. Diversity index value for Kayu Indah pole level is 1,20 and for tree level is 0,94 .

Base on the research result of 5 sample plots with $26 \mathrm{Ha}$ area with $5 \%$ sampling intensity it is known that stands which have highest diversity index value both for pole and tree level is Mahang (Macaranga sp) type, where sand for every pole is obtained total 312 stands with diversity index value 0,153 , while tree level stand is 94 and diversity index value is 0,137 and this is categorizes as low category.

Key words : Potency, pole, tree, level stand, diversity type.

\section{PENDAHULUAN}

Provinsi Kalimantan Timur memiliki 6 (Enam) KHDTK yaitu KHDTK Labanan, KHDTK Sebulu, KHDTK Samboja, KHDTK Penelitian dan Pendidikan UNMUL, KHDTK Kebun Raya Balikpapan dan KHDTK Hutan Pendidikan dan Pelatihan Loa Haur. KHDTK Hutan Pendidikan dan Pelatihan Loa Haur telah ditetapkan melalui Keputusan Menteri Kehutanan Nomor: SK. 8815/Kpts-II/2002 tanggal 24 September 2002 seluas 4.310 hektar.

Undang-undang No. 41 Tahun 1999 tentang kehutanan pada Pasal 8 telah mengakomodasi keperluan penelitian dan pengembangan,termasuk pendidikan dan pelatihan, religi dan budaya, melalui penetapan Kawasan Hutan Dengan Tujuan Khusus (KHDTK). KHDTK dapat berada pada hutan konservasi, hutan lindung ataupun hutan produksi dengan tidak mengubah fungsi pokok kawasan hutan tersebut yang pembentukannya dilakukan melalui Keputusan Menteri Kehutanan.

Sebagai instansi pendukung dalam sistem pembangunan kehutanan, Balai Diklat LHK Samarinda selain memiliki tugas pokok melaksanakan diklat aparatur dan non aparatur serta kerjasama diklat di bidang kehutanan, juga melaksanakan pengelolaan Kawasan Hutan Dengan Tujuan Khusus (KHDTK) Hutan Diklat Loa Haur.

Balai Diklat LHK Samarinda sebagai Unit Pelaksana Teknis Kementerian Lingkungan Hidup dan Kehutanan di Provinsi Kalimantan Timur telah memiliki Hutan Diklat seluas 4.310 hektar, hal ini sesuai dengan Surat Keputusan Menteri Kehutanan No. 8815/Kpts-II/2002 tanggal 24 September 2002. Keberadaan KHDTK Hutan Diklat Loa Haur secara kronologis dikukuhkan sejak tahun 1999 melalui Surat Sekjen Dephutbun No.1045/II-DIK/UM/1999 tanggal 22 April 1999 kepada Kepala 
Badan Planologi. Namun demikian sampai dengan saat ini hutan diklat belum bisa dimanfaatkan secara optimal yaitu sebagai sarana praktek lapangan bagi kegiatan pelatihan di Balai Diklat LHK Samarinda. Hal tersebut disebabkan karena selain infrastruktur (terutama jaringan jalan) yang masih belum sepenuhnya tersedia, juga keterbatasan dana untuk rencana pengelolaan kawasan hutan sehingga pengelolaannya dilaksanakan secara bertahap, terutama mengenai penataan areal hutan.

Potensi kawasan KHDTK Hutan Diklat Loa Haur berdasarkan survey potensi tahun 2009 adalah $41,97 \%$ berupa hutan sekunder muda, 34,78\% hutan sekunder tua dan sisanya berupa alangalang dan semak belukar. Jenis-jenis tegakan didominasi oleh jenis Arthocarpus sp, Anthocepalus cadamba, Syzgium sp, Dillenia sp. Sedangkan tegakan yang masih ditemukan namun tidak terlalu banyak adalah Eusideroxylon zwageri, Duabanga mollucana, Dipterocarpus sp, Shorea $\mathrm{sp}$ dan Dryobalanops aromatica

Dari uraian tersebut di atas salah satu kegiatan yang perlu dilaksanakan dalam rangka pembuatan rencana penataan dan pengembangan hutan diklat adalah dengan melakukan penelitian untuk mengidentifikasi potensi tegakan di dalam kawasan hutan diklat tersebut. Tujuan penelitian adalah: 1) mengetahui potensi tegakan tingkat Tiang di areal KHDTK Hutan Diklat Loa Haur Balai Diklat LHK Samarinda. 2) Mengetahui potensi tegakan tingkat Pohon di areal KHDTK Hutan Diklat Loa Haur Balai Diklat LHK Samarinda. 3) Mengetahui keanekaragaman jenis tegakan yang mendominasi areal KHDTK Hutan Diklat Loa Haur Balai Diklat LHK Samarinda.

\section{METODA PENELITIAN}

\subsection{Tempat dan Waktu}

Penelitian ini dilaksanakan di Kawasan Hutan Diklat Loa Haur Balai Diklat LHK Samarinda, secara administratif kawasan tersebut berada di Desa Batuah Kecamatan Loa Janan Kabupaten Kutai Kartanegara. Pada bulan JuliSeptember 2018.

\subsection{Objek dan Alat}

Objek yang diukur dalam penelitian ini adalah tegakan tingkat tiang dan pohon yang terdapat pada areal KHDTK Hutan Diklat Loa Haur Balai Diklat Lingkungan Hidup dan Kehutanan Samarinda.

Adapun peralatan yang digunakan dalam penelitian ini antara lain : Alatalat tulis dan tally sheet, Alat penentu arah (kompas), Pita diameter (phi band), Alat ukur tinggi pohon (Clino dan haga meter), Alat penentu posisi koordinat di lapangan (Global Positioning System/GPS merk GARMIN), Alat pengukur jarak (roll meter), Alat perintis jalur (parang), Kamera dan alat bantu pengolah data (kalkulator dan komputer).

\subsection{Prosedur Penelitian}

Penentuan plot penelitian, pelaksanaan pengukuran, pengukuran tegakan, perhitungan total volume dan keragaman jenis, analisis potensi tingkat tiang dan pohon.

\subsection{Pengambilan Data dan Informasi}

Pengambilan data dan informasi dilakukan secara langsung di lapangan, wilayah Desa Batuah Kecamatan Loa Janan Kabupaten Kutai Kartanegara yang terdiri dari : Observasi awal, yaitu kegiatan yang dilakukan untuk memperoleh data dan informasi awal yang digunakan untuk melengkapi penyusunan rencana kegiatan sebelum penelitian dilaksanakan. 
Inventarisasi hutan untuk mengetahui potensi tegakan pada areal KHDTK Hutan Diklat Loa Haur Balai Diklat LHK Samarinda.

\subsection{Metode Pengumpulan Data}

Pengambilan data primer diambil dan dikumpulkan langsung dari lokasi penelitian antara lain Tinggi Tegakan,
Diameter Tegakan, (Tegakan Tingkat Tiang dan Pohon). Data sekunder diambil dari beberapa dokumen sebelumnya baik dari Balai Diklat LHK Samarinda, Dinas Kehutanan Provinsi Kalimantan Timur maupun dari penelitian-penelitian sebelumnya untuk melengkapi data.

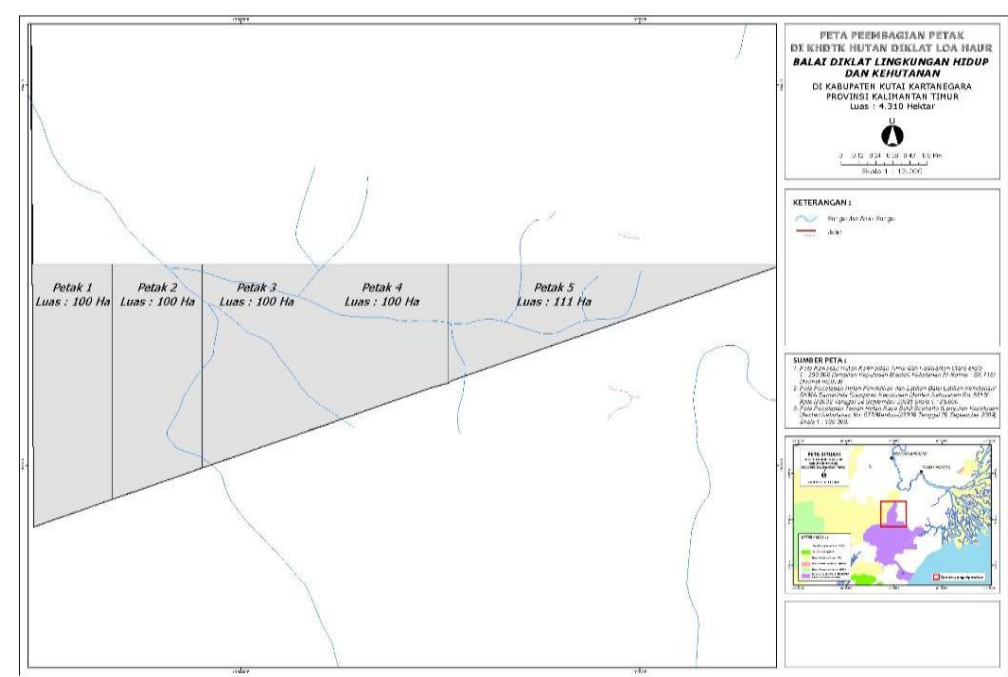

Gambar 1. Lokasi Penelitian dibagi kedalam petak penelitian ada 5 Petak penelitian, terdapat 4 petak penelitian dengan luas masing-masing 100 ha dan 1 petak penelitian dengan luas 111 ha.

\subsection{Analisis Data}

\subsubsection{Menghitung Volume Pohon}

Yaitu berat isi suatu pohon yang dihitung berdasarkan lingkaran pohon (diameter) yang biasanya diukur setinggi dada $(1,30 \mathrm{~m})$ dari permukaan tanah dan tinggi dari pangkal pohon sampai bebas cabang pertama, serta faktor bentuk pohon. Volume pohon di sini adalah volume pohon berdiri, dimana untuk perhitungannya digunakan rumus seperti di bawah ini.

$$
\begin{aligned}
& V=\frac{\pi\left(\frac{d}{100}\right)^{2} h f}{4} \\
& \text { dimana : } \\
& V \quad=\text { volume pohon }\left(\mathrm{m}^{3}\right) \\
& \pi \quad=\text { tetapan phi }(3,14159) \\
& d=\text { diameter pohon }(\mathrm{cm})
\end{aligned}
$$

$$
\begin{aligned}
& h \quad=\text { tinggi }(\mathrm{m}) \\
& f \quad=\text { faktor bentuk }=0,7
\end{aligned}
$$

\subsubsection{Menghitung Tinggi Tegakan}

Pengukuran tinggi dari pangkal pohon di permukaan tanah sampai puncak pohon dilakukan dengan hagameter. Tinggi pohon dihitung dengan rumus:

$$
\mathrm{H}=(\mathrm{H} 1-\mathrm{H} 2)
$$

$$
\begin{aligned}
& \text { Keterangan: } \\
& \begin{aligned}
\mathrm{H} & =\text { Tinggi Tegakan } \\
\mathrm{H} 1 & =\text { nilai tinggi untuk pembidikan } \\
& \text { tegakan bebas cabang } \\
\mathrm{H} 2 & =\text { nilai tinggi untuk pembidikan } \\
& \text { ke pangkal Tegakan }
\end{aligned}
\end{aligned}
$$

\subsubsection{Pengukuran Diameter}

Diameter diukur dengan menggunakan alat ukur Phi band. Phi band digunakan karena sudah memiliki kalkulasi besaran 
diameter dalam satuan $\mathrm{cm}$ pada tegakan dengan tinggi $1,30 \mathrm{~m}$ diatas permukaan tanah.

\subsubsection{Menghitung Nilai Rata-Rata Jumlah Pohon Per Hektar}

Yaitu rata-rata banyaknya pohon (diameter $\geq 20 \mathrm{~cm}$ ) yang tumbuh dalam suatu areal hutan untuk setiap hektarnya. Untuk mengetahui rata-rata jumlah pohon per hektarnya digunakan rumus sebagaimana di bawah ini.

$$
\bar{N}=\frac{\sum N}{\left(\frac{P x L}{10.000}\right)}
$$

dimana :

$\bar{N} \quad=$ rata-rata jml pohon per hektar (phn/ha)

$\sum N=$ jml pohon dalam jalur ukur (phn)

$P \quad=$ panjang jalur ukur $(\mathrm{m})$

$L \quad=$ lebar jalur ukur (m)

\subsubsection{Menghitung Nilai Keragaman Jenis}

Nilai keragaman Jenis dihitung dengan menggunakan rumus indeks diversitas dari Shannon-Wiener (Kent dan paddy, 1992; Smith dan Wilson, 1996; Spellerberg dan Fedor, 2003).

$H^{r}=-\sum_{i=1}^{s} \mathrm{Pi} \operatorname{Ln} \mathrm{Pi}$

$$
\mathrm{Pi}=n \mathrm{n} / \mathrm{N}
$$

Di mana:

$\mathrm{H}^{\prime}=$ Indeks keanekaragaman jenis

$\mathrm{ni}=$ Jumlah individu suatu jenis

$\mathrm{N}=$ Jumlah individu seluruh jenis

$\mathrm{Pi}=$ Proporsi jumlah individu jenis ke-i dengan jumlah individu semua jenis

$\mathrm{s}=$ Populasi individu semua jenis

Dengan Kriteria tingkat keanekaragaman jenis sebagai berikut :

- Tergolong Tinggi bila H' $>3,5$,

- Sedang bila $H^{\prime}=1,5-3,5$
- dan Rendah bila H' < 1,5

(Wahyudi, 2011; Iwan, 2012).

\section{HASIL PENELITIAN DAN PEMBAHASAN}

\subsection{Gambaran Umum Lokasi Penelitian}

Secara umum Hutan Diklat Loa Haur Balai Diklat LHK terletak antara $0^{\circ} 40^{\prime} 00^{\prime \prime} 0^{\circ} 46^{\prime} 00^{\prime \prime} \mathrm{LS}$ dan $116^{\circ} 6^{\prime} 00^{\prime \prime}$ $117^{\circ} 01^{\prime} 00$ BT. Secara administrasi pemerintahan, terletak dalam wilayah Kecamatan Loa Janan, Kabupaten Kutai Kartanegara. KHDTK HPP Loa Haur dapat dicapai melalui jalan darat, berjarak $\pm 7 \mathrm{~km}$ dari poros Samarinda Balikpapan Km 47. Hutan diklat Loa Haur terdapat di 3 (tiga) wilayah Pemerintahan Desa, yaitu Loa Duri Ulu, Loa Duri Ilir dan Bakungan.

Berdasarkan data curah hujan Tahun 2015 (Anonim, 2015), rata-rata curah hujan bulanan sebesar $183 \mathrm{~mm}$ dan rata-rata hari hujan per bulan sebesar 14 hari. Curah hujan tertinggi terjadi pada bulan Januari, yaitu sebesar $273 \mathrm{~mm}$ dengan 22 hari hujan, sedangkan curah hujan terendah terjadi pada bulan September, yaitu sebanyak $92 \mathrm{~mm}$ dengan 8 hari hujan (Anonim, 2015 ${ }^{\mathrm{a}}$ ). Menurut Sumaryono dkk. (2017), KHDTK HPP Loa Haur termasuk dalam tipe iklim A menurut Schmidt dan Ferguson dengan nilai $\mathrm{Q}<14,3 \%$ yang merupakan daerah sangat basah (hutan hujan tropis).

Sebagai bagian dari kawasan Tahura Bukit Soeharto, KHDTK HPP Loa Haur termasuk dalam kompleks bentukan fisiografi Lembah Kutai dan Jalur lipatan bukit (Kutai Valley and Ridge Fold Belts) yang secara umum bergelombang dengan ketinggian tempat antara 50-1500 meter (Anonim, 2006 dalam Sumaryono dkk, 2009). Mengacu pada Atlas East Kalimantan 
Transmigration Area Development Project/TAD, maka kondisi fisiografi dan topografi kawasan penelitian merupakan perbukitan yang memanjang dengan arah sejajar dengan jalur pantai dari Balikpapan ke Samboja, atau dari Balikpapan menuju timur laut kemudian di kawasan Samboja menuju ke utara. Posisi Tahura Bukit Soeharto ini terletak pada posisi yang tertinggi dan puncaknya adalah pada titik sekitar $\mathrm{km} 56$ jalan poros Samarinda-Balikpapan dengan ketinggian 145 meter dpl. Pada posisi demikian, Tahura Bukit Soeharto memberi pengaruh iklim kota Balikpapan dari kawasan laut sampai puncak tertinggi dengan iklim lautnya, sementara dari puncak tertinggi ke kota Samarinda dengan iklim daratnya.

Penutupan vegetasi kawasan Tahura Bukit Soeharto mempengaruhi kondisi iklim kota Balikpapan dan Samarinda. Bila penutupan kawasan vegetasi di Tahura Bukit Soeharto terbuka atau rusak maka kota Balikpapan yang mempunyai iklim lebih basah akan menjadi kering, sementara kota Samarinda yang kering menjadi lebih basah. Begitu sebaliknya bila tutupan vegetasi kawasan Tahura terjaga dengan vegetasi yang baik, maka iklim Balikpapan akan tetap basah, sementara Samarinda tetap kering (Sumaryono dkk, 2009).

Berdasarkan hasil analisis data dapat diketahui bahwa KHDTK HPP Loa Haur dominan datar hingga landai (0$15 \%$ ) yang terdapat di bagian Timur dan Selatan. Lokasi penelitian hanya sebesar 1,37\% kawasan dalam kelas kelerengan sangat curam (40\%), secara keseluruhan, semua kelas lereng tersebar sangat acak.

Berdasarkan peta Geologi Bersistem Indonesia Kalimantan skala 1: 250.000, formasi geologi di KHDTK HPP Loa Haur terdiri dari Batuan Sedimen Miosen Atas (Tumbul dan Sumaryono, 2017).
Seluruh kawasan KHDTK Hutan HPP Loa Haur termasuk dalam Daerah Aliran Sungan (DAS) Loa Haur. DAS ini berbatasan dengan 4 DAS lainnya, yaitu DAS Bakungan, DAS Dondang, DAS Seluang dan DAS Payang. Sumaryono dkk, (2009) mengemukakan bahwa jaringan sungai (drainage network) di KHDTK HPP Loa Haur bercirikan pola percabangan Pohon (dendritic pattern). Karena pengaruh faktor topografi dan kapasitas penampung yang terbatas, walaupun termasuk dalam tipe iklim A yang sangat basah dan curah hujan yang tinggi, potensi air di KHDTK HPP Loa Haur terbilang kecil karena limpasan air sungai yang relatif cepat.

\subsection{Potensi Tegakan Tingkat Tiang dan Pohon pada plot sampel Penelitian dengan intensitas $5 \%$ di KHD TK Loa Haur}

Potensi Tegakan Tingkat Tiang dan Pohon pada plot sampel 1 (satu) luas 5 ha (Intensitas 5\%)

Hasil inventarisasi tegakan hutan dilapangan pada plot sampel 1 dibagi ke dalam 3 kelompok jenis yaitu kelompok Meranti, Rimba campuran dan Kelompok Kayu indah, dimana masing-masing kelompok terdapat beberapa spesies tegakan dari tingkat Tiang maupun Pohon yang ditemukan pada KHDTK Hutan Diklat Loa Haur dan memiliki potensi yang berbeda-beda, pada plot sampel 1 hasil penelitian pada plot sampel 1 yang menunjukan bahwa Kelompok jenis Meranti memiliki 6 species yang mendominasi, akan tetapi yang paling banyak dijumpai yaitu Meranti Merah (352hore asp) sebanyak 3 tegakan pada klasifikasi struktur tegakan tingkat Tiang dengan volume sebesar $0,27 \mathrm{~m}^{3}$ dengan kubikasi $0,054 \mathrm{~m}^{3} / \mathrm{ha}$, sedangkan pada tingkat Pohon yang mendominasi adalah jenis Pulai (Alstonia scolaris) dengan jumlah 4 Pohon dengan volume sebesar 
$0,68 \mathrm{~m}^{3}$. Potensi tegakan tingkat Tiang dan Pohon kelompok jenis Meranti pada plot sampel 1 sebesar $2.41 \mathrm{~m}^{3}$ sama dengan $0,482 \mathrm{~m}^{3} / \mathrm{ha}$, dengan jumlah total 13 tegakan atau sama dengan 3 tegakan/ha.

Pada kelompok jenis Rimba campuran terdapat beberapa spesies tegakan hutan yang mendominasi pada plot sampel 1 yaitu Mahang (Macaranga sp) dangan jumlah 81 tegakan untuk tingkat Tiang dan 104 tegakan untuk tingkat Pohon, serta masing-masing memiliki potensi sebesar $9.01 \mathrm{~m}^{3}$ untuk tingkat Pohon dan $7.39 \mathrm{~m}^{3}$ untuk tingkat Tiang. Selanjutnya terbesar kedua yang mendominasi yaitu spesies Laban (Vitex $s p)$ dengan jumlah tegakan 62 untuk tingkat Tiang dan 83 tegakan untuk tingkat Pohon dengan potensi sebesar $12.98 \mathrm{~m}^{3}$ untuk tingkat Pohon dan 6.30 $\mathrm{m}^{3}$ untuk tingkat Tiang. Spesies ketiga yang mendominasi yaitu spesies Banitan (Xylopia sp) dengan jumlah tegakan 43 untuk tingkat Tiang dan 52 tegakan untuk tingkat Pohon dengan potensi sebesar $7,74 \mathrm{~m}^{3}$ untuk tingkat Pohon dan $4.60 \mathrm{~m}^{3}$ utnuk tingkat Tiang. Spesies keempat yang mendominasi yaitu spesies Anggrung (Trema orientalis) dengan jumlah tegakan sebanyak 21 tegakan untuk tingkat Tiang dan 29 tegakan untuk tingkat Pohon dengan potensi sebesar $4,23 \mathrm{~m}^{3}$ untuk tingkat Pohon dan $1,72 \mathrm{~m}^{3}$ utnuk tingkat Tiang.

Total keseluruhan terdapat 18 spesies dari kelompok jenis Rimba campuran pada plot sampel 1 dengan total jumlah populasi 262 dan potensi $26,08 \mathrm{~m}^{3}$ atau (52 populasi/ha dan potensi $5,216 \mathrm{~m}^{3} / \mathrm{ha}$ ) untuk tingkat Tiang dan 369 tegakan atau 74 tegakan/ha untuk tingkat Pohon dengan potensi sebesar 39, $30 \mathrm{~m}^{3}$ atau $7,80 \mathrm{~m}^{3} / \mathrm{ha}$.

Kelompok jenis kayu indah terdapat 4 spesies yang mendominasi yaitu Arau (Elmirillia tsiampacca), Dahu (Dracontomelon spp), $\quad$ Sengkuang
(Dracontomelon Dao) dan Ulin (Eusideroxylon zwageri). Spesies yang paling mendominasi adalah Ulin (Eusideroxylon zwageri).dengan jumlah 4 tegakan untuk tingkat Tiang dan 5 tegakan untuk tingkat Pohon total 9 populasi dengan potensi sebesar $2,44 \mathrm{~m}^{3}$, jumlah keseluruhan jenis untuk kelompok kayu indah ada 4 (empat) jenis, terdiri dari 7 (tujuh) populasi untuk tingkat Tiang dengan potensi sebesar $0,51 \mathrm{~m}^{3}$, dan 5 populasi untuk tingkat Pohon dengan potensi sebesar $1,93 \mathrm{~m}^{3}$. Pada plot sampel 1 Jika dirata-ratakan jumlah keseluruhan populasi tingkat Tiang sebanyak 278 tegakan atau 56 tegakan/ha dengan potensi sebesar $27,43 \mathrm{~m}^{3}$ atau $5,486 \mathrm{~m}^{3} /$ ha dan tingkat Pohon sebesar $42,80 \mathrm{~m}^{3}$ atau $8,56 \mathrm{~m}^{3} /$ ha dengan jumlah 116 populasi atau 23 populasi/ha.

Jumlah keseluruhan pada plot sampel 1 baik tingkat Tiang dan tingkat Pohon terdapat 394 populasi dengan volume $70,23 \mathrm{~m}^{3}$ atau sama dengan 79 populasi/ha dan $70,23 \mathrm{~m}^{3} / \mathrm{ha}$.

Potensi Tegakan Tingkat Tiang dan Pohon pada plot sampel 2 (dua) luas 5 ha (Intensitas 5\%)

Potensi tegakan tingkat Tiang dan Pohon beserta jumlah populasi masingmasing jenis pada plot sampel 2 luas 5 ha (Intensitas 5\%) menunjukan potensi tegakan hutan tingkat Tiang dan Pohon yang terbagi dalam 3 kelompok jenis. Didapatkan hasil antara lain : Untuk Kelompok Meranti terdapat 14 populasi dengan potensi sebesar $3,66 \mathrm{~m}^{3}$ atau sama dengan 3 populasi/ha dan potensi sebesar $0,732 \mathrm{~m}^{3} / \mathrm{ha}$, dengan rincian : pada kelompok Jenis meranti terdapat 7 jenis tegakan dengan jumlah populasi sebanyak 10 tegakan, untuk tingkat Tiang dan 4 populasi untuk tingkat Pohon. Jenis yang mendominasi dari tingkat Tiang dan Pohon adalah Pulai (Alstonia scolaris) dengan potensi sebesar $0.18 \mathrm{~m}^{3}$ sebanyak 2 tegakan pada tingkat Tiang potensinya 
sebesar $0.74 \mathrm{~m}^{3}$ untuk tingkat Pohon dengan jumlah tegakan 4 Pohon.

Berbeda dengan plot sampel 1 hasil yang didapatkan untuk kelompok jenis Rimba campuran lebih besar dengan jumlah spesies populasi sebanyak 21 jenis pada tingkat Tiang dan Pohon, sedangkan spesies yang mendominasi yaitu jenis Laban (Vitex sp) dengan jumlah 73 tegakan dan potnsi sebesar $7,30 \mathrm{~m}^{3}$ untuk tingkat Tiang dan 12 tegakan untuk tingkat Pohon dengan potensi sebesar $3,61 \mathrm{~m}^{3}$.

Jenis kedua yang mendominasi pada plot sampel 2 adalah kelompok Rimba Campuran yaitu jenis Mahang (Macaranga sp) jengan jumlah 59 tegakan atau 12 tegakan/ha dan potensinya sebesar $5 \mathrm{~m}^{3}$ atau $1 \mathrm{~m}^{3} / \mathrm{ha}$ utnuk tingkat Tiang dan 17 tegakan atau 3 tegakan/ha untuk tingkat Pohon dan potensi sebesar $5,44 \mathrm{~m}^{3}$ atau $1,088 \mathrm{~m}^{3} / \mathrm{ha}$, kemudian terdapat jenis Banitan (Xylopia sp) sebanyak 39 tegakan (8 tegakan/ha) dengan potensi sebesar $4,30 \mathrm{~m}^{3}(0,86$ $\mathrm{m}^{3} / \mathrm{ha}$ ) pada tingkat Tiang dan pada tingkat Pohon hanya 5 tegakan (1 tegakan/ha) dengan potensi $1,52 \mathrm{~m}^{3}$, $\left(0,304 \mathrm{~m}^{3} / \mathrm{ha}\right)$ selanjutnya jenis Terap (Arthocarpus spp) terdapat 21 tegakan (4 tegakan/ha) tingkat Tiang potensi sebesar $2,28 \mathrm{~m}^{3}\left(0,456 \mathrm{~m}^{3} / \mathrm{ha}\right)$ dan pada tingkat Pohon 16 tegakan (3 tegakan/ha) dengan potensi sebesar $6,35 \mathrm{~m}^{3}\left(1,27 \mathrm{~m}^{3} / \mathrm{ha}\right)$ jenis kelima terbanyak yang mendominasi adalah Anggrung (Trema orientalis) jumlah 18 tegakan (4 tegakan/ha) untuk tingkat Tiang dengan potensi sebesar $1,60 \mathrm{~m}^{3}\left(0,32 \mathrm{~m}^{3} / \mathrm{ha}\right.$ dan tingkat Pohon 16 tegakan (3 tegakan/ha) potensi sebesar $4,83 \mathrm{~m}^{3}\left(0,966 \mathrm{~m}^{3} / \mathrm{ha}\right)$ Jika dilihat pupulasi jenis yang mendominasi pada plot sampel 2 adalah sturktur tegakan tingkat Tiang sebanyak 247 populasi atau (49 populasi/ha) dari 21 jenis dan pada tingkat Pohon hanya 88 Pohon atau (18 Pohon/ha) dari 21 jenis.
Pada kelompok jenis Kayu Indah hanya terdapat 4 jenis yang mendominasi sama halnya dengan yang terdapat pada plot sampel 1 yaitu Arau (Elmirillia tsiampacca), Dahu (Dracontomelon spp), kayu Hitam (Dyiospiros bornensis) dan Ulin (Eusideroxylon zwageri). Spesies yang paling mendominasi adalah Ulin (Eusideroxylon zwageri). Yaitu dengan jumlah populasi sebanyak 5 tegakan atau (1 tegakan/ha) untuk tingkat Pohon dengan potensi $1,80 \mathrm{~m}^{3}$ atau $\left(0,36 \mathrm{~m}^{3} / \mathrm{ha}\right)$ dan tingkat Tiang terdapat 3 tegakan dengan potensi $0,15 \mathrm{~m}^{3}$ atau sama dengan $0,01 \mathrm{~m}^{3} /$ ha.

Potensi Tegakan Tingkat Tiang dan Pohon pada plot sampel 3 Luas $5 \mathrm{Ha}$ (Intensitas 5\%)

Potensi tegakan tingkat Tiang dan Pohon beserta jumlah populasi masingmasing jenis pada plot sampel 3 luas 5 ha (intensitas $5 \%$ ) Pada Plot sampel 3 ini diketahui bahwa Kelompok jenis Meranti ada 5 Jenis yang mendominasi, lebih sedikit dari plot sampel 2 dan plot sampel 1 jenis yang memiliki tegakan terbanyak adalah jenis Pulai (Alstonia scolaris) dengan 3 tegakan pada tingkat Pohon dengan potensi $0,81 \mathrm{~m}^{3}$ dan 1 tegakan pada tingkat Tiang dengan potensi 0.05 $\mathrm{m}^{3}$, jenis Durian (Durio zibethinus) hanya terdapat 1 tegakan pada tingkat Pohon, Kapur (Dryobalanops aromatica) hanya 1 tegakan pada tingkat Tiang dan meranti putih (Shorea sp) hanya 1 tegakan pada tingkat Tiang, sedangkan total potensi keseluruhan pada kelompok Meranti sebesar $1,74 \mathrm{~m}^{3}$ atau $\left(0,348 \mathrm{~m}^{3} / \mathrm{ha}\right)$ dengan jumlah tegakan 7 tegakan atau sama dengan 1 tegakan/ha.

Pada kelompok jenis Rimba Campuran terdapat 24 jenis dari total 262 populasi pada tingkat Tiang atau sama dengan 52 tegakan/ha dan 89 populasi dari tingkat Pohon atau sama dengan 18 tegakan/ha, lebih besar dari plot sampel 1 
dan plot sampel 2. Jenis dominan yang terdapat pada plot sampel 3 untuk kelompok Rimba Campuran yaitu jenis Mahang (Macaranga sp) sebanyak 78 tegakan pada tingkat Tiang dengan potensi $6,89 \mathrm{~m}^{3}$ atau (16 tegakan/ha dengan potensi $\left.1,378 \mathrm{~m}^{3} / \mathrm{ha}\right)$ dan 23 tegakan pada tingkat Pohon dengan potensi $9,51 \mathrm{~m}^{3}$ (5 tegakan/ha dan 1,902 $\mathrm{m}^{3} / \mathrm{ha}$ ) Jenis kedua yang mendominasi yaitu Laban (Vitex $s p$ ) sebanyak 74 tegakan dengan potensi $7,80 \mathrm{~m}^{3}$ atau (15 tegakan/ha dan $\left.1,56 \mathrm{~m}^{3} / \mathrm{ha}\right)$ dan 11 tegakan pada tingkat Pohon dengan potensi $3,36 \mathrm{~m}^{3}$ atau (2 tegakan/ha dan $\left.0,672 \mathrm{~m}^{3} / \mathrm{ha}\right)$. Selanjutnya jenis Banitan (Xylopia sp) dan Angrung (Trema orientalis) masing-masing memiliki 42 tegakan (8 tegakan/ha) dan 24 tegakan (5 tegakan/ha) pada tingkat Tiang, dengan potensi $4,08 \mathrm{~m}^{3}\left(0,816 \mathrm{~m}^{3} / \mathrm{ha}\right)$ dan 2,24 $\mathrm{m}^{3} \quad(0,448 / \mathrm{ha})$ untuk tingkat Pohon terdapat 8 tegakan (2 tegakan/ha) dan 15 tegakan (3 tegakan/ha) masing-masing memiliki potensi $3,19 \mathrm{~m}^{3}\left(0,638 \mathrm{~m}^{3} / \mathrm{ha}\right)$ dan $5,09 \mathrm{~m}^{3}\left(1,018 \mathrm{~m}^{3} / \mathrm{ha}\right)$ dan selebihnya terdapat jenis Binuang (Doubanga molucana), Jabon (Anthocepalus sp) serta jenis Jambu-jambu (Syzygium sp).

Untuk Kelompok jenis kayu indah terdapat 5 jenis yaitu Arau (Elmirillia tsiampacca), Bongin (Irvingia malayana), Dahu (Dracontomelon spp), kayu Hitam (Dyiospiros bornensis) dan Ulin (Eusideroxylon zwageri) sama halnya pada plot sampel 1 dan plot sampel 2, jenis yang banyak didapati yaitu Ulin (Eusideroxylon zwageri).

Potensi Tegakan Tingkat Tiang dan Pohon pada Plot Sampel 4 Luas 5 ha (Intensitas 5\%).

Pada plot sampel 4 kelompok jenis Meranti teridentifikasi sebanyak 7 jenis, kelompok Rimba Campuran sebanyak 18 jenis dan kelompok Kayu Indah terdapat 4 jenis. Potensi tegakan tingkat Tiang dan
Pohon beserta jumlah populasi masingmasing jenis pada plot sampel 4 yaitu: Jenis Kapur (Dryobalanops aromatica) dan Nyatoh (Palaqium rostatum) pada kelompok jenis meranti terdapat hanya pada tingkat Pohon dan hanya 1 tegakan yang ditemukan dengan volume potensi $0,040 \mathrm{~m}^{3}$ untuk Kapur dan $0,35 \mathrm{~m}^{3}$ untuk Nyatoh. Sedangkan pada tingkat Tiang hanya 3 jenis yang ada yaitu Keruing (Dipterocarpus sp), Meranti Merah (Shorea sp), Meranti Putih (Shorea sp) dimana jenis Meranti Merah yang paling banyak ditemukan, masing-masing jenis memiliki potensi yang berbeda yaitu 0,08 $\mathrm{m}^{3}$ untuk keruing, $0,50 \mathrm{~m}^{3}$ untuk meranti merah dan $0,05 \mathrm{~m}^{3}$ untuk meranti putih. Total potensi pada kelompok meranti yaitu $2,90 \mathrm{~m}^{3} \quad\left(0,58 \mathrm{~m}^{3} / \mathrm{ha}\right)$ dengan jumlah 15 populasi ( 3 populasi/ha) untuk tingkat Tiang dan Pohon.

Kelompok jenis Rimba Campuran terdapat 18 jenis yang di inventarisasi seperti pada plot sebelumnya jenis-jenis yang mendominasi yaitu Mahang (Macaranga sp), Laban (Vitex sp), Banitan (Xylopia sp) Angrung (Trema orientalis) dan Terap (Arthocarpus spp). Jumlah total populasi tingkat Tiang sebanyak 271 tegakan dengan potensi $25,31 \mathrm{~m}^{3}$ sedangkan unutk tingkat Pohon didapatkan 82 tegakan dengan potensi sebesar 33,51 $\mathrm{m}^{3}$. Sehingga jika ditotalkan untuk kelompok jenis Rimba Campuran pada plot sampel 4 didapatkan 353 tegakan dengan potensi sebesar 58,82 $\mathrm{m}^{3}$ atau (70 tegakan/ha) dan potensinya $\left.11.764 \mathrm{~m}^{3} / \mathrm{ha}\right)$. Selanjutnya untuk kelompok jenis Kayu Indah terdapat 4 jenis yaitu Dahu (Dracontomelon spp), Kayu hitam (Dyiospiros borneensis), Sengkuang (Dracontolmelon Dao) dan Ulin (Eusideroxylon zwageri) dimana terdapat 5 tegakan pada tingkat Tiang dan 9 tegakan pada tingkat Pohon, yang masing-masing memiliki potensi $0,53 \mathrm{~m}^{3}$ dan $3,48 \mathrm{~m}^{3}$ sehinggga total tegakan untuk kelompok jenis Kayu indah 
terdapat 14 tegakan dengan potensi 4,01 $\mathrm{m}^{3}$ atau sama dengan 3 tegakan/ha dengan potensi $0,082 \mathrm{~m}^{3} / \mathrm{ha}$.

Potensi Tegakan Tingkat Tiang dan Pohon pada Plot sampel 5 luas 6 ha (Intensitas 5\%)

Hasil yang didapatkan pada plot sampel 5 menunjukan perbedaan yang signifikan dari plot sampel penelitian 1 sampai denagn plot penelitian sampel 4 , dimana pada plot sampel 5 didapat hasil yang lebih kecil, hal dapat dilihat dari jumlah jenis populasi dan jumlah tegakan dari 3 kelompok jenis yaitu Kelompok Meranti, Kelompok Rimba Campuran dan Kelompok kayu indah . Potensi tegakan tingkat Tiang dan Pohon beserta jumlah populasi masing-masing jenis pada plot sampel 5 yaitu: jenis Meranti hanya terdapat 3 jenis yaitu Nyatoh (Palaqium rostatum), Pinang (Pentacea laxiflora) dan Pulai (Alstonia scolaris) yang hanya terdapat pada tegakan tingkat Pohon saja dengan jumlah 4 tegakan dan potensi $1,10 \mathrm{~m}^{3}$ atau sama dengan 0,22 $\mathrm{m}^{3} /$ ha. Pada kelompok jenis Rimba Campuran Hanya terdapat 14 jenis dengan Total jumlah 55 tegakan dengan potensi $4,37 \mathrm{~m}^{3}$ untuk tingkat Tiang atau sama dengan 9 tegakan/ha dan potensinya $0,728 \mathrm{~m}^{3} / \mathrm{ha}$, dan 81 tegakan untuk tingkat Pohon dengan potensi $30,78 \mathrm{~m}^{3}$ (14 tegakan/ha dan potensinya 5,13 $\mathrm{m}^{3} /$ ha, yang masih didominasi oleh jenis Laban (Vitex sp), Mahang (Macaranga sp) dan Banitan (Xylopia sp). Sedangkan pada kelompok jenis Kayu Indah hanya terdapat dua jenis antaralain Arau (Elmirillia tsiampacca) dan Ulin (Eusideroxylon zwageri) dan hanya terdapat ditingkat Pohon saja dengan jumlah 4 tegakan dan potensi 2,15 $\mathrm{m}^{3}$ atau sma dengan $0,358 \mathrm{~m}^{3} /$ ha.
Rekapitulasi Potensi Tegakan Tingkat Tiang dan Pohon Pada KHDTK Hutan Diklat Loa Haur.

Data rekapitulasi potensi tegakan tingkat Tiang dan Pohon dari plot sampel 1 sampai dengan plot sampel 5 (Luas 26 ha Intensitas 5\%), diketahui jumlah rekapitulasi keseluruhan dari plot-plot penelitian di KHDTK Hutan Diklat Loa Haur dimana tegakan yang diklasifikasikan dalam 3 kelompok jenis yaitu Kelompok Meranti, Kelompok Rimba Campuran dan Kelompok Kayu indah memiliki nilai yang beranekaragam. Untuk kelompok jenis meranti terdapat 11 jenis hasil inventarisasi dengan total keseluruhan populasi tegakan tingkat Tiang sebanyak 32 tegakan dengan potensi $2,96 \mathrm{~m}^{3}$ atau ( 1 tegakan/ha dan potensinya $0,11 \mathrm{~m}^{3} / \mathrm{ha}$ ) dan tingkat Pohon sebanyak 21 tegakan dengan potensi $8,85 \mathrm{~m}^{3}$ atau sama dengan 1 tegakan/ha dan potensinya $0,340 \mathrm{~m}^{3} / \mathrm{ha}$. Jumlah keseluruhan tegakan tingkat Tiang dan Pohona adalah 53 tegakan dan potensi sebesar $11,81 \mathrm{~m}^{3}$ sama dengan 2 tegakan/ha dan potensinya adalah 0,454 $\mathrm{m}^{3} /$ ha.

Kelompok jenis Rimba Campuran terdapat 30 jenis yang ada pada lokasi penelitian dengan jumlah tegakan sebenyak 1.097 tegakan dengan potensi sebesar 105,54 $\mathrm{m}^{3}$ untuk tingkat Tiang atau sama dengan 42 tegakan/ha dengan potensi $4,059 \mathrm{~m}^{3} / \mathrm{ha}$ dan 447 tegakan untuk tingkat Pohon dengan potensi $169,36 \mathrm{~m}^{3}$ atau sama dengan 17 tegakan/ha dengan potensi $6,514 \mathrm{~m}^{3} / \mathrm{ha}$. Jumlah total sebanyak 1.544 tegakan hutan dengan potensi sebesar $274,90 \mathrm{~m}^{3}$ atau sama dengan 59 tegakan/ha dengan potensi $10,573 \mathrm{~m}^{3} / \mathrm{ha}$.

Pada kelompok jenis kayu indah hanya terdapat 6 jenis dengan jumlah tegakan sebanyak 30 tegakan dengan potensi $2,50 \mathrm{~m}^{3}$ atau (1 tegakan/ha dan potensinya $0,96 \mathrm{~m}^{3} / \mathrm{ha}$ ) untuk tingkat Tiang, dan 29 tegakan untuk tingkat 
Pohon_dengan potensi $11,49 \mathrm{~m}^{3}$ sama dengan (1 tegakan/ha dan potensinya $0,441 \mathrm{~m}^{3} / \mathrm{ha}$ ). Jumlah keseluruhan untuk kelompok Kayu Indah sebanyak 59 tegakan dan potensi sebesar $13,99 \mathrm{~m}^{3}$ sama dengan 2 tegakan/ha dan potensinya sebesar $0,538 \mathrm{~m}^{3} / \mathrm{ha}$. Dari hasil penelitian terhadap plot-plot sampel sebanyak 5 plot sampel penelitian dengan luas 26 ha (intensitas 5\%) didapatkan hasil atau jumlah total tegakan sebanyak 1.656 tegakan dengan potensi sebesar 300,70 $\mathrm{m}^{3}$ sama dengan 64 tegakan/ha dan potensinya adalah sebesar $11,565 \mathrm{~m}^{3} / \mathrm{ha}$.

Total potensi keseluruhan yang didapat dari hasil penelitian dengan Intensitas $5 \%$ pada 5 plot sampel penelitian baik untuk tingkat Tiang dan tingkat Pohon didapat hasil sebesar 300,7 $\mathrm{m}^{3}$ atau $11,565 \mathrm{~m}^{3} / \mathrm{ha}$ dengan jumlah populasi 1.656 tegakan atau sama dengan 64 tegakan/ha, Bila dikonpersikan ke dalam areal penelitian seluas 511 ha pada KHDTK Hutan Diklat Loa Haur yang belum dilakukan pengelolaan maka akan didapatkan hasil atau jumlah potensi tegakan tingkat Tiang sebesar 2.181,459 $\mathrm{m}^{3}$ atau $\left(4,269 \mathrm{~m}^{3} / \mathrm{ha}\right)$ dengan jumlah populasi sebesar 22.995 tegakan (45 tegakan/ha), dan untuk tingkat Pohon potensi keseluruhan sebesar $3.730,30 \mathrm{~m}^{3}$ atau $7,30 \mathrm{~m}^{3} /$ ha dengan jumlah populasi sebanyak 9.709 tegakan atau 19 tegakan/ha, Maka bila dijumlahkan total potensi tingkat Tiang dan Pohon adalah sebesar 5.911,759 $\mathrm{m}^{3}$ atau sebesar 11,565 $\mathrm{m}^{3} /$ ha dengan jumlah populasi sebanyak 32.704481 tegakan atau sama dengan 63 tegakan/ha.

3.2. Nilai Indeks keragaman jenis pada KHDTK hutan diklat Loa Haur

Berdasarkan hasil perhitungan terhadap parameter kuantitatif Indeks keanekaragaman untuk tingkat Tiang nilai total indeks keanekaragaman jenis (H') yaitu 2,14 yang nilai tersebut menandakan bahwa indeks keanekaragaman komunitas (H') dalam kategori sedang dengan kriteria $\mathrm{H}^{\prime}$ 1-3 atau tingkat keanekaragaman kategori sedang (Shannon-Wiener 1992). Sedangkan untuk tingkat Pohon Nilai indek keragaam 1,72 masih tergolong sedang (Shannon-Wiener, Kent dan Paddy, 1992; Smith dan Wilson, 1996; Spellerberg dan Fedor, 2003; Wahyudi, 2011; Iwan, 2012). Sama halnya dengan Tingkat Tiang. Jenis yang mendominasi pada Kelompok Meranti tingkat Tiang yaitu Meranti Merah (Shorea $s p$ ) dengan nilai indek keanekaragaman sebesar 0,36 dan indeks keanekaraganan yang paling kecil terdapat pada tiga jenis yaitu Bangkirai (Shorea laefvifolia), Durian (Durio Zibethinus) dan Jelutung (Dyera costulata) dengan nilai indeks 0,11 . Untuk tingkat Pohon jenis dengan nilai keanekaragaman paling besar adalah Pulai (Alstonia $s p$ ) dengan nilai 0,36. Nilai-nilai indeks keanekaragaman tersebut masih termasuk dalam kategori Rendah (Shannon-Wiener, Kent dan Paddy, 1992; Smith dan Wilson, 1996; Spellerberg dan Fedor, 2003; Wahyudi, 2011; Iwan, 2012).

Indeks keanekaragaman jenis pada kelompok Jenis Rimba Campuran didapatkan nilai keanekaragaman jenis pada tingkat Tiang dengan nilai indeks 1,98 masih dalam kategori sedang kriteria H' 1-3 atau tingkat keanekaragaman jenis sedang, sedangkan untuk tingkat Pohon didapatkan nilai 2,31 yang masuk kategori tergolong sedang (ShannonWiener, Kent dan Paddy, 1992; Smith dan Wilson, 1996; Spellerberg dan Fedor, 2003; Wahyudi, 2011; Iwan, 2012). Jenis yang memiliki keanekaragaman tinggi pada tingkat Tiang adalah Banitan (Xylopia sp) dengan nilai indek 0,30, sedangkan yang paling kecil dengan nilai indeks 0,01 ada beberapa jenis diantaranya Binuang bini (Octomeles sumatrana), Darah darah (Meristika 
maxima), Jabon (Anthocepalus cadamba), Kenanga (Cananga odorata), Manggis (Garcinia sp), Puspa (Schima walicii), Putat (Baringtonia pendula) dan Tebu Itam (Saccharum officinarum Liin). Untuk tingkat Pohon jenis yang memiliki Keanekaragan tinggi adalah Banitan (Xylopia sp)) dengan nilai 0,33 dan yang paling rendah dengan nilai indeks keranekaragaman 0,01 terdiri dari Binuang (Duabanga moluccana), Darah darah (Myristica sp), Laban (Vitex pubescan), Manggis (Garcinia sp) dan Semangkok (Scaphium macropodum). pembagian golongan keanekaragaman jenis tersebut Berdasarkan Baku Mutu Lingkungan. Ditunjukkan bahwa keanekaragaman $\quad 0,00-0,07$ tergolong sangat rendah, 0,08- 0,15 tergolong rendah, 0,16-0,23 tergolong sedang, 0,24-0,31 tergolong tinggi dan diatas 0,32 tergolong sangat tinggi (Kepmen KLH Nomor 02 tahun 1988).

Nilai keanekaragaman jenis kelompok jenis kayu Indah pada tingkat Tiang dengan nilai indeks 1,20 masuk dalam kategori sedang dengan kriteria H' 1-3 sedangkan pada tingkat Pohon didapatkan nilai 0,94 masuk kriteria $\mathrm{H}^{\prime}<$ 1,5 , hal ini menunjukan bahwa tinggkat keanekaragaman jenis tinggkat Pohon masih tergolong rendah (ShannonWiener, Kent dan Paddy, 1992; Smith dan Wilson, 1996; Spellerberg dan Fedor, 2003; Wahyudi, 2011; Iwan, 2012).

Nilai keanekaragaman jenis pada tingkat Tiang didominasi oleh jenis Ulin (Eusideroxylon zwageri) dengan nilai indeks 0,29, sedangkan keanekaragaman jenis yang paling kecil adalah Bongin (Irvingia malayana) dengan nilai 0,11 . Pada tingkat Pohon ulin masih memiliki nilai indeks yang tinggi dengan nilai 0,23 serta jenis yang lain diantaranya Arau (Elmirillia tsiampacca) dan Kayu hitam (Dyiospiros borneensis) yang terendah adalah jenis Dahu (Dracontomelon spp) dengan nilai keanekaragaman 0,12 . Nilainilai indeks tersebut masih dalam kategori Rendah (Shannon-Wiener, Kent dan Paddy, 1992; Smith dan Wilson, 1996; Spellerberg dan Fedor, 2003; Wahyudi, 2011; Iwan, 2012).

Nilai indeks keanekaragaman jenis berdasarkan jenis pada lokasi penelitian seluas 511 ha dengan pengambilan sampel seluas 26 ha (intensitas 5\%) dapat dilihat pada Tabel 1 dibawah ini. 
Tabel 1. Nilai Indeks keanekaragaman jenis berdasarkan jenis pada lokasi penelitian luas 511 ha dengan pengambilan sampel seluas 26 ha (Intensitas 5\%)

\begin{tabular}{|c|c|c|c|c|c|c|c|}
\hline \multirow{3}{*}{ No. } & \multirow{3}{*}{ Nama / Jenis } & \multicolumn{4}{|c|}{ Klasifikasi Tegakan } & \multirow{2}{*}{\multicolumn{2}{|c|}{ Jumlah Tegakan }} \\
\hline & & \multicolumn{2}{|c|}{ Tiangkat Tiang } & \multicolumn{2}{|c|}{ Tingkat Pohon } & & \\
\hline & & $\mathrm{N}$ & $\mathrm{H}^{\prime}$ & $\mathrm{N}$ & $\mathrm{H}^{\prime}$ & $\mathrm{N}$ & $\mathrm{H}^{\prime}$ \\
\hline $\mathbf{1}$ & 2 & 3 & 4 & 5 & 6 & 7 & 8 \\
\hline 1 & Mahang (Macaranga sp) & 312 & 0,153 & 94 & 0,137 & 406 & 0,290 \\
\hline 2 & Laban (Vitex sp) & 303 & 0,152 & 74 & 0,123 & 377 & 0,275 \\
\hline 3 & Banitan (Xylopia sp) & 179 & 0,125 & 44 & 0,093 & 223 & 0,219 \\
\hline 4 & Angrung (Trema orientalis) & 88 & 0,085 & 66 & 0,116 & 154 & 0,201 \\
\hline 5 & Terap (Arthocarpus spp) & 76 & 0,078 & 47 & 0,097 & 123 & 0,174 \\
\hline 6 & Jabon (Anthocephalus sp) & 22 & 0,033 & 19 & 0,054 & 41 & 0,087 \\
\hline 7 & Binuang (Duabanga moluccana) & 21 & 0,032 & 1 & 0,005 & 22 & 0,037 \\
\hline 8 & Simpur (Dillenia sp) & 21 & 0,032 & 43 & 0,092 & 64 & 0,124 \\
\hline 9 & Ulin (Eusideroxylon zwageri) & 19 & 0,029 & 21 & 0,058 & 40 & 0,087 \\
\hline 10 & Jambu-jambu (Syzygium sp) & 17 & 0,027 & 11 & 0,037 & 28 & 0,064 \\
\hline 11 & Bayur (Pterospermum celebicum) & 13 & 0,022 & 12 & 0,039 & 25 & 0,061 \\
\hline 12 & Meranti Merah (Shorea sp) & 9 & 0,016 & - & 0,000 & 9 & 0,016 \\
\hline 13 & Kayu Pasang (Quercus sp) & 8 & 0,015 & 9 & 0,032 & 17 & 0,046 \\
\hline 14 & Pulai (Alstonia scolaris) & 7 & 0,013 & 3 & 0,013 & 10 & 0,027 \\
\hline 15 & Keledang (Artocarpus elasticus) & 6 & 0,012 & 4 & 0,017 & 10 & 0,029 \\
\hline 16 & Laban (Vitex pubescan) & 5 & 0,010 & 3 & 0,013 & 8 & 0,024 \\
\hline 17 & Keruing (Dipterocarpus sp) & 4 & 0,008 & 1 & 0,005 & 5 & 0,014 \\
\hline 18 & Nyatoh (Palaqium rostatum) & 4 & 0,008 & 3 & 0,013 & 7 & 0,022 \\
\hline 19 & Banitan (Mezzetia parvifolia) & 4 & 0,008 & 7 & 0,026 & 11 & 0,035 \\
\hline 20 & Dahu (Dracontomelon spp) & 4 & 0,008 & 2 & 0,010 & 6 & 0,018 \\
\hline 21 & Bayur (Pterospermum sp) & 3 & 0,007 & 5 & 0,020 & 8 & 0,027 \\
\hline 22 & Cempedak (Artocarpus champeden) & 3 & 0,007 & - & 0,000 & 3 & 0,007 \\
\hline 23 & Medang (Litsea maxima) & 3 & 0,007 & - & 0,000 & 3 & 0,007 \\
\hline 24 & Arau (Elmirillia tsiampacca) & 3 & 0,007 & 3 & 0,013 & 6 & 0,020 \\
\hline 25 & Kapur (Dryobalanops lanceolata) & 2 & 0,005 & 1 & 0,005 & 3 & 0,010 \\
\hline 26 & Pinang (Pentacea laxiflora) & 2 & 0,005 & 2 & 0,010 & 4 & 0,014 \\
\hline 27 & Darah darah (Meristika maxima) & 2 & 0,005 & - & 0,000 & 2 & 0,005 \\
\hline 28 & Manggis (Garcinia sp) & 2 & 0,005 & 1 & 0,005 & 3 & 0,010 \\
\hline 29 & Rambutan (Nephelium lappaceum) & 2 & 0,005 & 8 & 0,029 & 10 & 0,034 \\
\hline 30 & Tebu Itam (Saccharum officinarum Liin) & 2 & 0,005 & - & 0,000 & 2 & 0,005 \\
\hline 31 & Kayu hitam (Dyiospiros borneensis) & 2 & 0,005 & 3 & 0,013 & 5 & 0,018 \\
\hline 32 & Bangkirai (Shorea laefvifolia) & 1 & 0,003 & - & 0,000 & 1 & 0,003 \\
\hline 33 & Durian (Durio Zibethinus) & 1 & 0,003 & 1 & 0,005 & 2 & 0,008 \\
\hline 34 & Jelutung (Dyera costulata) & 1 & 0,003 & - & 0,000 & 1 & 0,003 \\
\hline 35 & Meranti Putih (Shorea sp) & 1 & 0,003 & 1 & 0,005 & 2 & 0,008 \\
\hline 36 & Benuang bini (Octomeles sumatrana) & 1 & 0,003 & - & 0,000 & 1 & 0,003 \\
\hline 37 & Jabon (Anthocepalus cadamba) & 1 & 0,003 & - & 0,000 & 1 & 0,003 \\
\hline 38 & Kenanga (Cananga odorata) & 1 & 0,003 & - & 0,000 & 1 & 0,003 \\
\hline 39 & Puspa (Schima walicii) & 1 & 0,003 & - & 0,000 & 1 & 0,003 \\
\hline 40 & Putat (Baringtonia pendula) & 1 & 0,003 & - & 0,000 & 1 & 0,003 \\
\hline 41 & Bongin (Irvingia malayana) & 1 & 0,003 & - & 0,000 & 1 & 0,003 \\
\hline 42 & Sengkuang (Dracontolmelon Dao) & 1 & 0,003 & 2 & 0,010 & 3 & 0,012 \\
\hline 43 & Darah darah (Myristica sp) & - & 0,000 & 1 & 0,005 & 1 & 0,005 \\
\hline 44 & Gerunggang (Cratoxylon sp) & - & 0,000 & 2 & 0,010 & 2 & 0,010 \\
\hline 45 & Rambai (Baccaurea motleyana) & - & 0,000 & 2 & 0,010 & 2 & 0,010 \\
\hline 46 & Semangkok (Scaphium macropodum) & - & 0,000 & 1 & 0,005 & 1 & 0,005 \\
\hline & Jumlah III & 1.159 & 0,957 & 497 & 1,128 & 1.656 & 2,086 \\
\hline
\end{tabular}

Ket : N = Jumlah Populasi, H’ = Nilai Indeks Keanekaragaman Jenis.

Berdasarkan Tabel 1 diatas diketahui bahwa Jumlah Jenis yang terdapat pada lokasi penelitian seluas 511 ha dengan pengambilan sampel seluas 26 ha (Intensitas sampel 5\%) didapat sebanyak 46 Jenis, dan berdasarkan hasil perhitungan nilai indeks keanekaragaman jenis $\mathrm{H}^{\prime}$ diketahui bahwa jenis yang mempunyai nilai indeks keanekaragaman $\mathrm{H}^{\prime}$ tertinggi baik untuk tegakan tingkat 
Tiang dan tegakan tingkat Pohon adalah jenis Mahang (Macaranga sp), Untuk tegakan tingkat Tiang didapat sebanyak 312 tegakan dengan nilai indeks keanekaragaman jenisnya 0,153 .

Dan untuk tegakan tingkat Pohon diperoleh sebanyak 94 tegakan dengan nilai indeks keanekaragaman jenisnya sebesar 0,137 . Nilai indeks ini baik untuk tegakan tingkat Tiang dan tegakan tingkat Pohon masih termasuk dalam kategori Rendah (Shannon-Wiener, Kent dan Paddy, 1992; Smith dan Wilson, 1996; Spellerberg dan Fedor, 2003; Wahyudi, 2011; Iwan, 2012).

\section{KESIMPULAN}

Berdasarkan hasil pembahasan
dapat ditarik beberapa kesimpulan
sebagai berikut : 1) Berdasarkan hasil
rekapitulasi dari 5 petak penelitian seluas 511 ha dengan pengambilan sampel plot seluas 26 ha (intensitas 5\%) yang berada pada Areal KHDTK Hutan Diklat Loa Haur yang belum dilakukan pengelolaan diperoleh tegakan sebanyak 46 Jenis dengan jumlah populasi sebanyak 1.656 populasi, dengan rrincian adalah Populasi tingkat Tiang sebanyak 1.159 tegakan dan populasi tingkat Pohon sebanyak 497 tegakan. 2) Berdasarkan Hasil rekapitulasi dari 5 petak penelitian seluas 511 ha dengan pengambilan sampel plot seluas 26 ha (Intensitas 5\%) yang berada pada Areal KHDTK Hutan Diklat Loa Haur yang belum dilakukan pengelolaan diperoleh Potensi tegakan tingkat Tiang sebesar $111 \mathrm{~m}^{3}$ atau sama dengan 4,269 $\mathrm{m}^{3} /$ ha dengan jumlah populasi sebanyak 1.159 tegakan sama dengan 45 tegakan/ha. 3) Berdasarkan Hasil rekapitulasi dari 5 petak penelitian seluas 511 ha dengan pengambilan sampel plot seluas 26 ha (Intensitas 5\%) yang berada pada KHDTK Hutan Diklat Loa Haur yang belum dilakukan pengelolaan diperolah Potensi tegakan tingkat Pohon sebesar $189,7 \mathrm{~m}^{3}$ atau sama dengan 7,30 $\mathrm{m}^{3} /$ ha dengan jumlah populasi sebanyak 497 tegakan sama dengan 19 tegakan/ha. 4) Jumlah keseluruhan baik tegakan tingkat Tiang dan tegakan tingkat Pohon, berdasarkan hasil rekapitulasi dari 5 petak penelitian seluas 511 ha dengan pengambilan sampel seluas 26 ha (Intensitas 5\%) diperoleh potensi sebesar $300,70 \mathrm{~m}^{3}$ atau sama dengan 11,565 $\mathrm{m}^{3} /$ ha dengan jumlah tegakan sebanyak 1.656 tegakan atau sama dengan 64 tegakan/ha. 5) Nilai indek keanekaragaman jenis H' pada kelompok jenis Meranti tingkat Tiang sebesar 2,14 dan tingkat pohon sebesar 1,72, pada kelompok jenis Rimba Campuran Nilai indeks Keanekaragaman jenis tingkat Tiang sebesar 1,98 dan tingkat Pohon sebesar 2,31. Pada kelompok jenis ini nilai indeks keanekaragaman jenisnya termasuk dalam kategori Sedang (Shannon-Wiener, Kent dan Paddy, 1992; Smith dan Wilson, 1996; Spellerberg dan Fedor, 2003; Wahyudi, 2011; Iwan, 2012). 6) Pada kelompok Jenis Kayu Indah nilai indeks Keanekaragaman jenis tingkat Tiang sebesar 1,20 dan tingkat Pohon 0,94 nilai H' pada kelompok ini nilai indeks keanekaragaman jensnya termasuk dalam kategori Rendah, (Shannon-Wiener, Kent dan Paddy, 1992; Smith dan Wilson, 1996; Spellerberg dan Fedor, 2003; Wahyudi, 2011; Iwan, 2012). 7) Nilai Indeks keanekaragaman jenis $H^{\prime}$ berdasarkan jenisnya, untuk tegakan tingkat Tiang, jenis yang memiliki nilai indeks keanekaraganan jenis tertinggi adalah jenis Mahang (Macaranga sp) yaitu 0,153, dan tegakan tingkat Pohon jenis yang memiliki nilai indeks keanekaragaman jenis $\mathrm{H}^{\prime}$ tertinggi juga jenis Mahang (Macaranga sp) yaitu dengan nilai indeks keanekaragaman jenis sebesar 0,137. Nilai indeks ini masih termasuk dalam kategori Rendah (Shannon-Wiener, Kent dan Paddy, 1992; 
Smith dan Wilson, 1996; Spellerberg dan Fedor, 2003; Wahyudi, 2011; Iwan, 2012).

\section{UCAPAN TERIMA KASIH}

Kami ucapkan terima kasih kepada pengelola Kawasan Hutan Dengan Tujuan Khusus (KHDTK) Hutan Diklat Loa Haur Balai Diklat LHK Samarinda yang telah memberikan fasilitas dalam penelitian ini.

\section{DAFTAR PUSTAKA}

Anonim, 1989. Kamus Kehutanan Edisi Pertama. Departemen Kehutanan Republik Indonesia.

Anonim, 1997. Diktat Panduan Pelatihan Pengukuran dan Pemetaan Sumalindo A-II Materi Inventarisasi Hutan. Pusat Pendidikan dan Pelatihan PT. Sumalindo Lestari Jaya Samarinda.

Anonim, 1999. Undang-Undang Republik Indonesia Nomor 41 Tahun 1999 Tentang Kehutanan.

Dewobroto, K.S. dkk. 1989. Kamus Konservasi Sumber Daya Alam. Departemen Pendidikan dan Kebudayaan. Penerbit PT. Rineka Cipta Jakarta.

Dwiatmo, S. 1989. Ensiklopedi Konservasi Sumber Daya. Penerbit Erlangga Jakarta.

Simon, H. 1996. Metoda Inventore Hutan. Penerbit Aditya Media Yogyakarta.

Zain, A.S. 1998. Kamus Kehutanan. Penerbit PT. Rineka Cipta Jakarta.

Creswell, J. W. 2012. Reseach design pendekatan kualitatif, kuantitatif, dan mixed. Yogyakarta: Pustaka Pelajar
Fowler, E. J. 2002. Survey research methods $\left(3^{r d} e d\right)$. Thousand Oaks, CA: Sage

Hartanto, R. 2003. Modul metodologi penelitian. Semarang: Universitas Diponegoro

Latham, B. 2007. Sampling: What is it?. Diakses pada 2 Desember 2018

dihttp://webpages.acs.ttu.edu/rlath am/Coursework/5377\%29\%29/Sa mpling_Methodology_Paper.pdf

Nasution, R. 2003. Teknik sampilng. Makalah USU digital library. Diakses pada tanggal 2 Desember 2018 dari http://library.usu.ac.id/download/ fkm/fkm-rozaini.pdf

Neuman, W. L. 2007. Basic of social research: Qualitative and quantitative qpproaches, second edition. Pearson Education, Inc.

Teddlie, C. \& Yu, F. 2007. Mixed Methods Sampling: A Typology With Examples. Journal of Mixed Method Research, 2007; 1; 77. Sage Publication.

Weiner, I. 2003. Handbook of psychology vol.02: Research methods inpsychology. John Wiley \& Son Inc: New Jersey

Zainuddin, M.(2011. Metodologi penelitian kefarmasian dan kesehatan.Surabaya: Airlangga University Press.

Kent, M., dan Paddy, C., 1992. Vegetation Description and Analysis A Practical Approach. Belhaven Press, London.

Smith, B., dan Wilson, J.B., 1996, A Consumer's Guide To Evenness Indices, Oikos, 70-82 
Spellerberg, I.F., dan Fedor, P.J., 2003, Atribute to Claude Shannon (1916-2001) And A Plea For More Rigorous Use Of Species Richness, Species Diversity and The 'Shannon-Wiener'Index, Global Ecology and Biogeography, 12(3):177-179.

Iwan, H., 2012. Komposisi Jenis dan Struktur Tegakan pada Areal Bekas Tebangan di PT Salaki
Summa Sejahtera, Provinsi Sumatera Barat. Jurnal Silvikultur Tropika, 3(3):155-160.

Wahyudi, A. , Sugeng P., Harianto, dan Darmawan, A., 2014. Keanekaragaman Jenis Pohon Di Hutan Pendidikan Konservasi Terpadu Tahura Wan Abdul Rachman. Jurnal Sylva Lestari, 2(3):1-10. 